\title{
Selective Determination of Oxalate with a Ruthenium(II) Complex/Nafion-Modified Electrode Combined with a Carbon Dioxide Sensor
}

\author{
Naoyoshi Egashira, Hirofumi Kumasako, Yoshiaki Kurauchi and Kazuya OHga \\ Department of Applied Chemistry, Faculty of Engineering, Oita University, \\ Dannoharu, Oita 870-11, Japan
}

\begin{abstract}
A tris(2,2'-bipyridine)ruthenium(II)/Nafion-modified $\mathrm{Pt}$ gauze electrode, where $\mathrm{CO}_{2}$ was generated by oxidation of substrates, was combined with a $\mathrm{CO}_{2}$ sensor. The combined sensor responded most effectively to oxalate among the organic acids examined. The response to oxalate was enhanced by use of a doubly-piled, modified $\mathrm{Pt}$ gauze electrode. The most suitable applied potential was $+0.95 \mathrm{~V} v s . \mathrm{Ag} / \mathrm{AgCl}$; the stationary response was attained in $10 \mathrm{~min}$ after the potential application. The response to $0.5 \mathrm{mM}$ oxalate was reproducible within $3 \%$ on 10 repeated runs and remained virtually unchanged over 10 days. The calibration curve for oxalate was linear in the concentration range of 0.1 to $5 \mathrm{mM}$, and the detection limit was $0.05 \mathrm{mM}(S / N=3)$.
\end{abstract}

Keywords Oxalate, tris(2,2'-bipyridine)ruthenium(II), Nafion, modified electrode, carbon dioxide sensor

The determination of oxalate is important in the fields of food chemistry and clinical chemistry. At present there are many methods for such determination, including potassium permanganate titration ${ }^{1}$, gas chromatography $^{2}$, colorimetry ${ }^{3}$ and enzyme assay. ${ }^{4}$ These methods, however, are time-consuming and cannot be used for on-line determination. Flow-through detectors consisting of an enzyme thermistor column ${ }^{5,6}$ have the problem that unstable or expensive enzymes must be used.

We previously reported two types of fiber-optic electrochemiluminescence (ECL) sensors for the determination of oxalate. One of the sensors consisted of a $\mathrm{Pt}$ working electrode coated with tris(2,2'-bipyridine)ruthenium(II) $\left(\left[\mathrm{Ru}(\mathrm{bpy})_{3}\right]^{2+}\right) / \mathrm{Nafion}^{7}{ }^{7}$ the other was a carbon paste electrode containing bis(2,2'-bipyridine)-4,4'dinonadecyl-2,2'-bipyridine)ruthenium(II). ${ }^{8}$ Performances of these sensors, however, were unsatisfactory: the former was sensitive to trialkylamines as well and the latter, in addition to similar low selectivity, needed troublesome repacking of the carbon paste before each measurement.

In the present work, we fabricated an oxalate sensor having a $\left[\mathrm{Ru}(\mathrm{bpy})_{3}\right]^{2+} /$ anionic perfluoropolymer (Nafion)-modified electrode combined with a $\mathrm{CO}_{2}$ sensor which responds to $\mathrm{CO}_{2}$ generated by the following reaction sequence: 9

$$
\begin{aligned}
& {\left[\mathrm{Ru}(\mathrm{bpy})_{3}\right]^{2+} \longrightarrow\left[\mathrm{Ru}(\mathrm{bpy})_{3}\right]^{3+}+\mathrm{e},} \\
& {\left[\mathrm{Ru}(\mathrm{bpy})_{3}\right]^{3+}+(\mathrm{COO})_{2} 2^{2-} \longrightarrow\left[\mathrm{Ru}(\mathrm{bpy})_{3}\right]^{2+}} \\
& +(\mathrm{COO})_{2}{ }^{-},
\end{aligned}
$$

$$
(\mathrm{COO})_{2}{ }^{\circ} \longrightarrow \mathrm{CO}_{2}{ }^{\circ}+\mathrm{CO}_{2}
$$

and

$$
\left[\mathrm{Ru}(\mathrm{bpy})_{3}\right]^{2+}+\mathrm{CO}_{2}{ }^{-} \longrightarrow\left[\mathrm{Ru}(\mathrm{bpy})_{3}\right]^{+}+\mathrm{CO}_{2}
$$

This sensor exhibited essentially no response to trialkylamines.

\section{Experimental}

\section{Reagents}

$\mathrm{Ru}(\mathrm{bpy})_{3} \mathrm{Cl}_{2}$ and $5 \mathrm{wt} \%$ Nafion solution in aqueous lower aliphatic alcohols were from Aldrich. All other reagents were of reagent grade or better and were used without further purification.

\section{Preparation of the $R u^{\prime \prime}$ complex-modified electrode}

A Nafion-modified electrode was prepared by dropping $60 \mu \mathrm{l}$ of the Nafion solution on a piece of Pt gauze (80 mesh, $16 \mathrm{~mm}$ in diameter) and evaporating this solution to dryness at room temperature. The modified electrode was dipped in a $1 \mathrm{mM}\left[\mathrm{Ru}(\mathrm{bpy})_{3}\right]^{2+} /$ aqueous solution for $3 \mathrm{~h}$ to incorporate the $\mathrm{Ru}^{\mathrm{II}}$ complex into the Nafion film and subsequently rinsed with deionized water.

\section{Apparatus and procedure}

As shown in Fig. 1, the $\left[\mathrm{Ru}(\mathrm{bpy})_{3}\right]^{2+} /$ Nafion electrode was doubly piled and was fixed on the bottom face of a TOA CE235 $\mathrm{CO}_{2}$ sensor coupled with a TOA 1M.1E Ion 

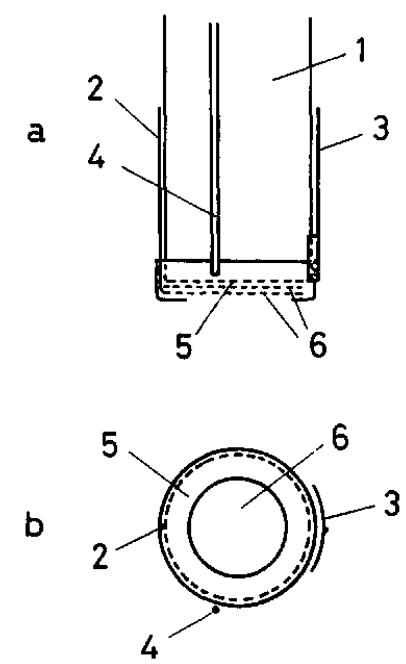

Fig. 1 Configuration of the end of the sensor: (a) side view, (b) bottom view: $1, \mathrm{CO}_{2}$ sensor; 2, $\mathrm{Pt}$ wire; 3 , counter electrode ( $\mathrm{Pt}$ plate); $4, \mathrm{Ag} / \mathrm{AgCl}$ electrode; $5, \mathrm{CO}_{2}$ sensor membrane; 6, working electrode ( $\mathrm{Pt}$ gauze modified with $\left[\mathrm{Ru}(\mathrm{bpy})_{3}\right]^{2+} /$ perfluoropolymer $)$.

Meter. A Pt counter electrode $(12 \times 22 \mathrm{~mm})$ and $\mathrm{Ag} /$ $\mathrm{AgCl}$ reference electrode $(1 \mathrm{~mm} \phi)$ were fixed on the side face. The working electrode potential was $+0.95 \mathrm{~V} v s$. $\mathrm{Ag} / \mathrm{AgCl}$, controlled with a Hokuto Denko HA-301 potentiostat, unless otherwise noted. The current was monitored with an Advantest TR6846 Digital Multimeter. The electrolytic solution was $10 \mathrm{~cm}^{3}$ of $0.2 \mathrm{M}$ phosphate buffer of $\mathrm{pH} 6.9$ thermostated at $25.0 \pm 0.1^{\circ} \mathrm{C}$, except in studying the $\mathrm{pH}$ effect, where $0.2 \mathrm{M}$ phthalate buffer was used at pH 4.4 and $0.2 \mathrm{M}$ phosphate buffer at $\mathrm{pH} 6.2,6.9$ and 7.7. A freshly prepared sensor was subjected to aging until a stable response to $1 \mathrm{mM}$ oxalate was obtained.

\section{Results and Discussion}

Figure 2 shows a typical response when the sensor was immersed into a $0.5 \mathrm{mM}$ oxalate solution under stirring. The signal gradually increased until it reached a stationary value $10 \mathrm{~min}$ after application of the potential.

As shown in Fig. 3, the response to a $1 \mathrm{mM}$ oxalate solution with the $\left[\mathrm{Ru}(\mathrm{bpy})_{3}\right]^{2+}$-modified electrode was detectable at $+0.6 \mathrm{~V}$; it increased with a rise in potential, reaching a constant value at $+1.0 \mathrm{~V}$. A preferable potential was determined to be $+0.95 \mathrm{~V}$, in view of the accelerated decay of the response at higher potentials. At $+0.95 \mathrm{~V}$, a very weak response to $0.2 \mathrm{M}$ phosphate buffer was also observed and therefore was subtracted from the response intensity with the substrate solution. A response to oxalate with an unmodified electrode was detectable only at potentials over $+1.0 \mathrm{~V}$ in the presence of $0.1 \mathrm{mM}\left[\mathrm{Ru}(\mathrm{bpy})_{3}\right]^{2+}$, showing the high electroactivity of the modified electrode because of a high concentration of $\left[\mathrm{Ru}(\mathrm{bpy})_{3}\right]^{2+}$ in the film. The response in the absence of the $\mathrm{Ru}^{\mathrm{II}}$ complex with the bare electrode, probably due

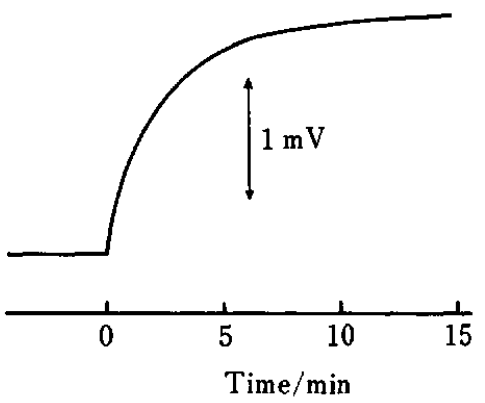

Fig. 2 Response profile of the sensor to $0.5 \mathrm{mM}$ oxalate in $0.2 \mathrm{M}$ phosphate buffer of $\mathrm{pH}$ 6.9. Applied potential: $+0.95 \mathrm{~V}$ vs. $\mathrm{Ag} / \mathrm{AgCl}$.

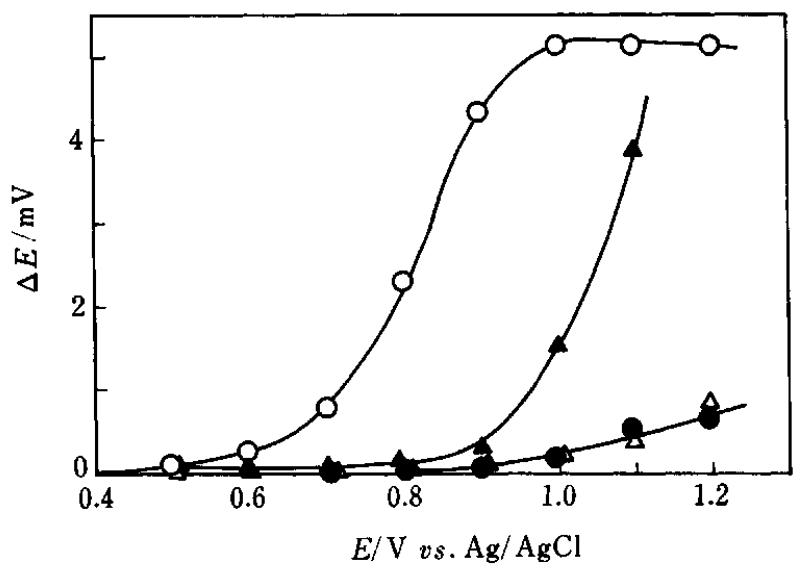

Fig. 3 Effects of the appplied potential on responses of the $\left[\mathrm{Ru}(\mathrm{bpy})_{3}\right]^{2+}$-modified electrode to $0.2 \mathrm{M}$ phosphate buffer of pH 6.9 containing $1 \mathrm{mM}$ oxalate $(O)$ and to the phosphate buffer containing no oxalate (O) and on responses of a bare Pt electrode to the buffer containing $1 \mathrm{mM}$ oxalate $(\triangle)$ and to the buffer containing $1 \mathrm{mM}$ oxalate and $0.1 \mathrm{mM}\left[\mathrm{Ru}(\mathrm{bpy})_{3}\right]^{2+}$ (A).

to the Kolbe reaction, was negligible below $+1.0 \mathrm{~V}$.

Piling two or three of the $\left[\mathrm{Ru}(\mathrm{bpy})_{3}\right]^{2+} / \mathrm{Nafion}-$ modified electrodes was examined. The doubly piled electrode gave a signal intensity 1.2 times as large as that of a singly-piled electrode and, in addition, the latter showed a slower response rate. It thus seems that the outside Pt gauze of the doubly-piled electrode kept the generated $\mathrm{CO}_{2}$ from diffusing into the bulk solution. The triple pile did not enhance the signal intensity further, and consequently the doubly-piled electrode was chosen.

Figure 4 shows the effect of solution $\mathrm{pH}$ on the response to oxalate. The largest net response was observed at $\mathrm{pH} 6.2$, while the net response at around $\mathrm{pH}$ 7 was not so much reduced and thus was sufficient to apply to in vivo measurements.

The signal intensity for $0.5 \mathrm{mM}$ oxalate was reproducible within $3 \%$ on 10 repeated runs. The response was so stable as to give almost the same intensity even after repeated use of 10 days, suggesting that the present sensor is applicable to practical use. Figure 5 


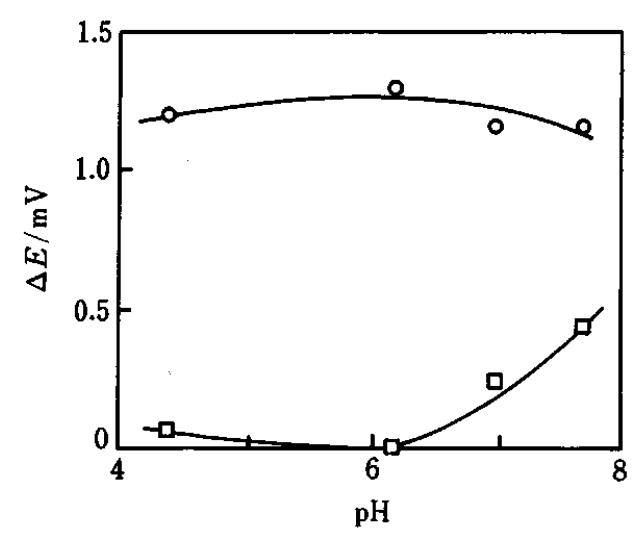

Fig. $4 \mathrm{pH}$-Dependence of the response to $0.5 \mathrm{mM}$ oxalate $(O)$ and a buffer solution without oxalate ( $\square$ ). Applied potential, +0.95 V vs. $\mathrm{Ag} / \mathrm{Ag} \mathrm{Cl}$.

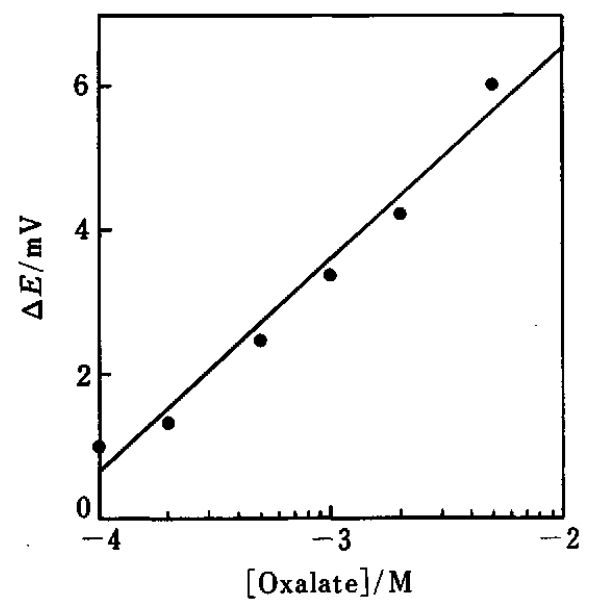

Fig. 5 Calibration curve for oxalate in $0.2 \mathrm{M}$ phosphate buffer of $\mathrm{pH}$ 6.9. Applied potential, $+0.95 \mathrm{~V} v$ s. Ag/AgCl.

shows a linear calibration curve for oxalate in the concentration range of 0.1 to $5 \mathrm{mM}$ (correlation coefficient, 0.971). The detection limit was $0.05 \mathrm{mM}(S / N=3)$, sufficient to determine oxalate in vegetables and urine ranging in concentration from 0.1 to $3 \mathrm{mM}$. The performance of the present sensor was comparable with those of the flow-through detectors mentioned above..$^{5,6}$

The response intensities for several organic substrates are summarized in Table 1 . No response was observed with tripropylamine as expected. On the other hand, the sensor responded to some other carboxylic acids and amino acids, albeit more weakly than to oxalate. Accordingly, care must be taken in handling a sample solution where the responsive acids coexist. In the case of urine, particularly, uric acid coexisting in the concentration of a few $\mathrm{mM}$ should be previously removed by electrooxidation at a proper potential.

A substrate to which the sensor strongly responds must have an oxidation potential low enough to reduce the electrochemically generated $\left[\mathrm{Ru}(\mathrm{bpy})_{3}\right]^{3+}$, and the oxidized intermediate must undergo an efficient decarboxylation or degradation leading to $\mathrm{CO}_{2}$ generation if
Table 1 Relative intensities for organic substrates in $0.2 \mathrm{M}$ phosphate buffer of $\mathrm{pH} 6.9$

\begin{tabular}{|c|c|c|}
\hline Substrate $^{\mathbf{a}}$ & $\begin{array}{l}\text { Relative } \\
\text { intensity }^{\mathrm{b}}\end{array}$ & $\begin{array}{c}E_{\mathrm{p}} / \mathrm{V} \\
\nu S . \\
\mathrm{SCE}^{\mathrm{c}}\end{array}$ \\
\hline Oxalic acid & 100 & 1.38 \\
\hline Formic acid & 14 & $-d$ \\
\hline Pyruvic acid & 0 & 1.52 \\
\hline 3-Methyl-2-oxobutanoic acid & 4 & \\
\hline 4-Methyl-2-oxopentanoic acid & 0 & 1.45 \\
\hline Oxalacetic acid & 59 & 1.55 \\
\hline 2-Oxoglutaric acid & 14 & - \\
\hline Lactic acid & 6 & - \\
\hline Malic acid & 6 & - \\
\hline Tartaric acid & 7 & - \\
\hline Glycine & 0 & \\
\hline Phenylglycine & 0 & \\
\hline Leucine & 0 & \\
\hline Phenylalanine & 0 & \\
\hline Proline & 0 & \\
\hline Aspartic acid & 7 & \\
\hline Glutamic acid & 9 & \\
\hline Serine & 8 & \\
\hline Homoserine & 8 & \\
\hline Threonine & 0 & \\
\hline Cysteine & 10 & \\
\hline Methionine & 0 & \\
\hline Histidine & 17 & \\
\hline Tryptophan & 5 & \\
\hline Asparagine & 13 & \\
\hline Arginine & 0 & \\
\hline Uric acid & 26 & 0.42 \\
\hline Tripropylamine & 0 & \\
\hline
\end{tabular}

a. $5 \times 10^{-4} \mathrm{M}$.

b. Applied potential, $+0.95 \mathrm{~V} v$ s. $\mathrm{Ag} / \mathrm{AgCl}$.

c. Anodic peak potential $E_{\mathrm{p}}$ measured in $0.2 \mathrm{M}$ phosphate buffer of $\mathrm{pH} 6.8$ by cyclic voltammetry on a glassy carbon electrode.

d. Not observed.

$\mathrm{CO}_{2}$ is generated only through a series of reactions starting with a one-electron oxidation of the substrate with the $\left[\mathrm{Ru}(\mathrm{bpy})_{3}\right]^{3+}$ complex, as illustrated by equations (1) - (3) for oxalate. Oxalacetic acid exhibited a strong response, though it has a higher oxidation potential than those of other $\alpha$-keto acids, 4-methyl-2oxopentanoic acid, 2-oxoglutaric acid and pyruvic acid. Uric acid with a very low oxidation potential showed a weaker response than those of oxalate and oxalacetic acid. Thus, the response intensity appears to depend not only on the oxidation potential but also on the efficiency of the decarboxylation or degradation process, though this point should be substantiated by further studies. The highest response of oxalic acid may be attributed partly to generation of two $\mathrm{CO}_{2}$ molecules through a series of reactions (2)-(4).

In conclusion, the present sensor is applicable to the selective oxalate determination and also to the determination of trialkylamines, when combined with 
the ECL sensor which can respond to both oxalate and trialkylamines. ${ }^{7}$

\section{References}

1. K. Herrmann, Z. Lebensm, Unters. Forsch., 155, 220 (1974).

2. I. Yamashita, T. Tamura, S. Yoshikawa, T. Shimamoto and A. Matsumoto, Nippon Nogei Kagaku Kaishi, 48, 151 (1974).

3. K. Nakahara, Eiyo to Shokuryo, 27, 33 (1974).

4. A. R. Hilary, N. M. Kennedy, S. M. Kulwant and I. M. Alasdair, Clin. Chim. Acta, 182, 247 (1989).
5. B. Danielsson, B. Mattiasson and K. Mosbach, "Applied Biochemistry and Bioengineering", Vol. 3, p. 97, Academic Press, New York, 1981.

6. F. Winguist, B. Danielsson, J-Y. Malpote, L. Persson and M-B. Larsson, Anal. Lett., 18, 573 (1985).

7. N. Egashira, H. Kumasako and K. Ohga, Anal. Sci., 6, 903 (1990).

8. N. Egashira, N. Kondoh, Y. Kurauchi and K. Ohga, Denki Kagaku, 60, 1148 (1992).

9. I. Rubinstein and A. J. Bard, J. Am. Chem. Soc., 103, 512 (1981).

(Received January 12, 1994) (Accepted March 25, 1994) 